\title{
Up-Regulation of Amino Acid Transporter SLC6A19 Activity and Surface Protein Abundance by PKB/Akt and PIKfyve
}

\author{
Evgenii Bogatikova* Carlos Munoz ${ }^{\text {a* }}$ Tatsiana Pakladok ${ }^{\mathrm{a}}$ Ioana Alesutan ${ }^{\mathrm{a}}$ Manzar

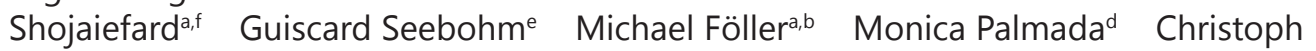 \\ Böhmer $^{d}$ Stefan Bröerc ${ }^{c}$ Florian Lang ${ }^{a}$
}

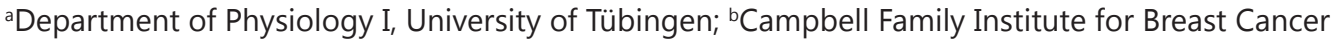
Research, Ontario Cancer Institute, University Health Network (UHN), 620 University Avenue, Toronto, Ontario; 'Research School of Biology, Australian National University, Canberra; dRhine-Waal University of Applied Sciences, Kleve; 'Biochemistry I, Ruhr University Bochum, Bochum; fDepartment of Physiology, Fasa University of Medical Science, Fasa; *contributed equally and thus share first authorship
\end{abstract}

\section{Key Words}

Amino acid uptake $\cdot$ PKB/Akt $• \mathrm{~B}^{0}$ AT1 $・$ PIKfyve

\begin{abstract}
Background: The amino acid transporter B ${ }^{0} \mathrm{AT} 1$ (SLC6A19) accomplishes concentrative cellular uptake of neutral amino acids. SLC6A19 is stimulated by serum- \& glucocorticoid-inducible kinase (SGK) isoforms. SGKs are related to PKB/Akt isoforms, which also stimulate several amino acid transporters. PKB/Akt modulates glucose transport in part by phosphorylating and thus activating phosphatidylinositol-3-phosphate-5-kinase (PIKfyve), which fosters carrier protein insertion into the cell membrane. The present study explored whether PKB/Akt and/or PIKfyve stimulate SLC6A19. Methods: SLC6A19 was expressed in Xenopus oocytes with or without wild-

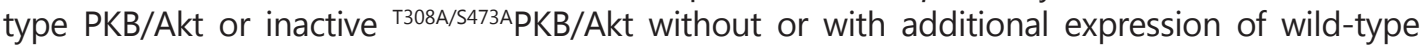
PIKfyve or PKB/Akt-resistant S318APIKfyve. Electrogenic amino acid transport was determined by dual electrode voltage clamping. Results: In SLC6A19-expressing oocytes but not in water-injected oocytes, the addition of the neutral amino acid L-leucine $(2 \mathrm{mM})$ to the bath generated a current $\left(\mathrm{I}_{\mathrm{le}}\right)$, which was significantly increased following coexpression of PKB/Akt, but not by coexpression of ${ }^{T 308 A / 5473 A}$ PKB/Akt. The effect of PKB/Akt was augmented by additional coexpression of PIKfyve but not of S318APIKfyve. Coexpression of PKB/Akt enhanced the maximal transport rate without significantly modifying the affinity of the carrier. The decline of $\mathrm{I}_{\mathrm{le}}$ following inhibition of carrier insertion by brefeldin A ( $5 \mu \mathrm{M})$ was similar in the absence and presence of PKB/Akt indicating that PKB/Akt stimulated carrier insertion into rather than inhibiting carrier retrieval from the cell membrane. Conclusion: PKB/Akt up-regulates SLC6A19 activity, which may foster amino acid uptake into PKB/Akt-expressing epithelial and tumor cells.




\section{Introduction}

The concentrative cellular uptake of several neutral amino acids including L-leucine into epithelial cells of the small intestine and of the proximal tubule of the kidney is accomplished by the $\mathrm{Na}^{+}$-coupled transporter $\mathrm{B}^{\circ} \mathrm{AT} 1$ (SLC6A19) [1-4]. Loss of function mutations of SLC6A19 lead to Hartnup disease, a classical autosomal recessive disorder with aminoaciduria resulting in several clinical symptoms such as photo-sensitive skinrash, cerebellar ataxia, pellagra, dementia and late-onset seizures [3, 5-7]. SLC6A19 is under powerful regulation by the angiotensin-converting enzyme 2 (ACE2) and collectrin [3].

SLC6A19 has further been shown to be regulated by the serum-\& glucocorticoidinducible kinase isoforms SGK1-3 [8]. The SGKs share a variety of targets with PKB/Akt, which has previously been shown to stimulate the activity of several amino acid transporters [9-16]. PKB/Akt- and SGK-dependent regulation of transporters involves in part the phosphorylation and activation of the mammalian phosphatidylinositol-3-phosphate-5kinase PIKfyve, a kinase generating phosphatidylinositol 3,5-bisphosphate $\left(\mathrm{PI}(3,5) \mathrm{P}_{2}\right)[17$ 20]. PIKfyve regulates endosomal transport [21-25] and plays a critical role in the regulation of the glucose carrier GLUT4 [26-28], the $\mathrm{Na}^{+}$-glucose cotransporter SGLT1 [29], the creatine transporter CreaT [30], the $\mathrm{Cl}^{-}$channels CFTR [31] and ClC2 [32], the $\mathrm{Ca}^{2+}$ channel TRPV6 [33], the $\mathrm{K}^{+}$channel KCNQ1/KCNE1 [30] and the excitatory amino acid transporters [34, 35].

The present study explored, whether PKB/Akt regulates SLC6A19 and if so, whether PIKfyve is involved in this process. To this end, SLC6A19 activity was estimated from L-leucineinduced current utilizing dual electrode voltage clamp in Xenopus oocytes expressing SLC6A19

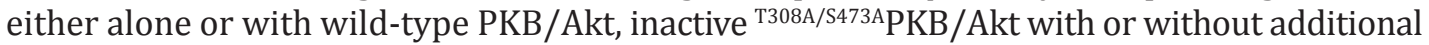

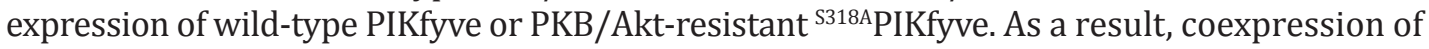
$\mathrm{PKB} /$ Akt but not of ${ }^{\mathrm{T} 308 \mathrm{AS} 473 \mathrm{~A}} \mathrm{PKB} /$ Akt enhanced electrogenic L-leucine transport in SLC6A19expressing Xenopus oocytes, an effect augmented by additional expression of PIKfyve, but not of ${ }^{\text {S318APIKfyve. }}$

\section{Materials and Methods}

\section{Constructs}

For generation of cRNA the following cDNA constructs were used: Wild-type SLC6A19 [8], HA-tagged

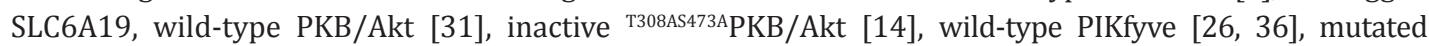
s318A PIKfyve lacking the SGK/PKB/Akt phosphorylation consensus sequence $[26,30]$ and wild-type Collectrin [8]. PKB/Akt cDNA was kindly provided by Sir Philip Cohen, College of Life Sciences, Sir James Black Centre, University of Dundee. HA-tagged SLC6A19 was generated by two-stage PCR site-directed mutagenesis using the primers:

SLC6A19-HA, S:

5' GTGGAAGAGTGTTACGACGTACCAGATTACGCTGCCAAGAGCTC 3’;

SLC6A19-HA, as:

5' GAGCTCTTGGC AGCGTAATCTGGTACGTCGTAACACTCTTCCAC 3'.

The mutant was sequenced to verify the presence of the desired mutation. The mutants were used for generation of cRNA as described previously [35].

\section{Voltage clamp in Xenopus oocytes}

For voltage clamp analysis, Xenopus oocytes were prepared as previously described [37]. On the day of preparation, Xenopus laevis oocytes were injected with water or cRNA encoding SLC6A19 (25 ng) with or without cRNA encoding collectrin (10 ng). One day later cRNA encoding wild-type PKB/Akt (10 ng), mutant

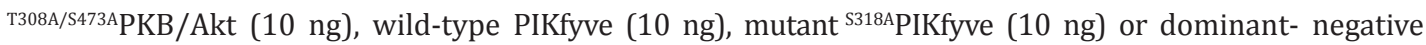
$\mathrm{PIKfyve}^{\mathrm{K} 1831 \mathrm{E}}$ (10 ng) was injected. The oocytes were maintained at $17^{\circ} \mathrm{C}$ in ND96-A solution containing 88.5 $\mathrm{mM} \mathrm{NaCl}, 2 \mathrm{mM} \mathrm{KCl}, 1.8 \mathrm{mM} \mathrm{MCaCl}, 1 \mathrm{mM} \mathrm{MgCl}_{2}, 5 \mathrm{mM}$ HEPES, $0.11 \mathrm{mM}$ tretracycline, $4 \mu \mathrm{M}$ ciprofloxacin, $0.2 \mathrm{mM}$ gentamycin (Refobacin (C), $0.5 \mathrm{mM}$ theophylline (Euphylong (C) as well as $5 \mathrm{mM}$ sodium pyruvate. The $\mathrm{pH}$ was adjusted to 7.4 by addition of $\mathrm{NaOH}$. Where indicated, brefeldin $\mathrm{A}(5 \mu \mathrm{M}$, Sigma, Schnelldorf, 
Germany) was added. The voltage-clamp experiments were performed at room temperature 3 days after the last injection [38]. Two-electrode voltage-clamp recordings were performed at a holding potential of $-60 \mathrm{mV}$. Data were filtered at $10 \mathrm{~Hz}$ and recorded with Digidata 1322A converter and Clampex V.9 software for data acquisition and analysis (Axon Instruments, Union City, CA, USA). ND96 was used as the control superfusate (96 mM NaCl, $2 \mathrm{mM} \mathrm{KCl}, 1.8 \mathrm{mM} \mathrm{CaCl}_{2}, 1.0 \mathrm{mM} \mathrm{MgCl}_{2}, 5 \mathrm{mM}$ HEPES, titrated to $\mathrm{pH} 7.4$ by $\mathrm{NaOH}$ ). L-leucine was added to the solutions at a concentration of $2 \mathrm{mM}$ unless otherwise stated. The flow rate of the superfusion was approx. $20 \mathrm{ml} / \mathrm{min}$, and a complete exchange of the bath solution was reached within about $10 \mathrm{~s}$ [39].

\section{Detection of SLC6A19 cell surface expression by chemiluminescence}

To determine SLC6A19 cell surface expression by chemiluminescence [34], oocytes were first incubated with $0.5 \mu \mathrm{g} / \mathrm{mL}$ primary rat anti-HA High Affinity antibody (Roche, Switzerland) and subsequently with a secondary, HRP-conjugated anti-rat IgG antibody (1:1000, Cell signaling Technology, MA, USA) Individual oocytes were placed in 96 well plates with $20 \mu \mathrm{l}$ of SuperSignal ELISA Femto Maximum Sensitivity Substrate (Pierce, Rockford, IL, USA) and chemiluminescence of single oocytes was quantified in a luminometer (Walter Wallac 2 plate reader, Perkin Elmer, Juegesheim, Germany) by integrating the signal over a period of $1 \mathrm{sec}$. Results display normalized relative light units.

\section{Statistical analysis}

Data are provided as arithmetic means \pm SEM; $n$ represents the number of oocytes investigated. All oocyte experiments were repeated with at least three batches of oocytes and in all repetitions qualitatively similar data were obtained. All data were tested for significance by using ANOVA or t-test, as appropriate. Results with $\mathrm{p}<0.05$ were considered statistically significant.

\section{Results}

The present study explored the effect of PKB/Akt coexpression on SLC6A19 (B AT)dependent amino acid transport. To this end, cRNA encoding SLC6A19 was injected into Xenopus oocytes with or without additional injection of cRNA encoding PKB/Akt. Electrogenic amino acid transport was then determined with the dual electrode voltage clamp technique. Addition of L-leucine $(2 \mathrm{mM})$ to the bath induced a small inward current in water-injected Xenopus oocytes, indicating that expression of endogenous electrogenic transport of L-leucine was low in Xenopus oocytes (Fig. 1). In Xenopus oocytes expressing SLC6A19, however, L-leucine $(2 \mathrm{mM})$ induced an inward current $\left(\mathrm{I}_{\mathrm{le}}\right)$ pointing to electrogenic entry of $\mathrm{Na}^{+}$together with L-leucine (Fig. 1). As illustrated in Fig. 1, $\mathrm{I}_{\mathrm{le}}$ was significantly enhanced by additional expression of PKB/Akt. In contrast to wild-type PKB/Akt, the inactive mutant ${ }^{\text {T308AS473A }}$ PKB/Akt did not significantly modify the activity of SLC6A19 (Fig. 1).

As shown in Fig. 1C, the coexpression of collectrin resulted in a $17 \pm 6$ fold increase in $\mathrm{I}_{\mathrm{le}}(\mathrm{n}=9)$. The additional coexpression of PKB/Akt in SLC6A19- and collectrin-expressing oocytes was followed by a further $45 \pm 15 \%(\mathrm{n}=11)$ increase in $\mathrm{I}_{\mathrm{le}}$. Thus, PKB/Akt increased SLC6A19-mediated transport both, in the presence and absence of collectrin.

According to kinetics analysis of L-leucine-induced currents in SLC6A19-expressing Xenopus oocytes (Fig. 2) the maximal current was $27.8 \pm 0.2 \mathrm{nA}$ and the L-leucine concentration required for halfmaximal current $\left(\mathrm{K}_{\mathrm{M}}\right)$ approached $520 \pm 22 \mu \mathrm{M}$, if SLC6A19 was expressed alone. The coexpression of SLC6A19 and PKB/Akt significantly increased the maximal current to $46.2 \pm 0.4 \mathrm{nA}$ but did not significantly alter $\mathrm{K}_{\mathrm{M}}(576 \pm 26 \mu \mathrm{M})$. Accordingly, coexpression of PKB/Akt enhanced SLC6A19 activity by increasing the maximal current without significantly influencing the affinity of the carrier.

As PKB/Akt is known to regulate GLUT4 via phosphorylation and thus activation of PIKfyve, additional experiments were performed exploring the impact of PIKfyve on SLC6A19 activity. As illustrated in Fig. 3, in Xenopus oocytes expressing SLC6A19 together with PKB/ Akt, the additional coexpression of PIKfyve resulted in a further significant increase in $\mathrm{I}_{\mathrm{le}}$. In contrast, the additional expression of PKB/Akt-resistant ${ }^{\text {S318APIKfyve did not significantly }}$ modify $\mathrm{I}_{\mathrm{le}}$ in SLC6A19- and PKB/Akt-coexpressing Xenopus oocytes. In the presence of 
Fig. 1. Coexpression of PKB/Akt but not of ${ }^{\text {T308AS473APKB/Akt stimulated }}$ electrogenic L-leucine transport in SLC6A19expressing Xenopus oocytes. A: Representative original tracings showing L-leucine (2 mM)-induced current $\left(\mathrm{I}_{\mathrm{le}}\right)$ in Xenopus oocytes injected with water (a), expressing SLC6A19 without (b) or with (c) additional coexpression of wild-type PKB/Akt or of the inactive mutant

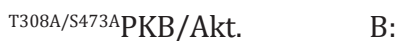
Arithmetic means \pm SEM ( $n=5-45$ ) of the normalized L-leucine (2 mM)-induced current $\left(\mathrm{I}_{\mathrm{le}}\right)$ in Xenopus oocytes injected with water (dotted bar), or expressing SLC6A19 without (white bar) or with additional coexpression of wild-type

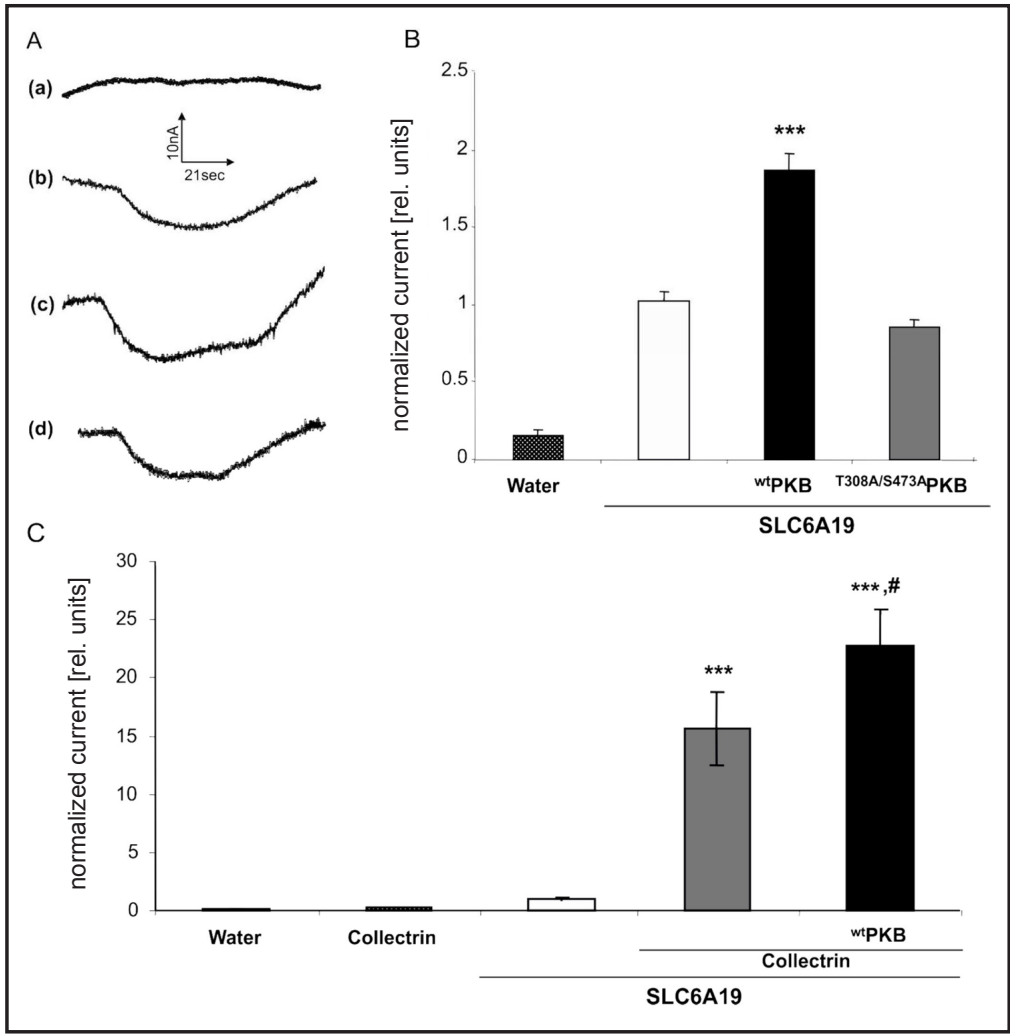

$\mathrm{PKB} /$ Akt (black bar) or of the inactive mutant ${ }^{\mathrm{T} 308 \mathrm{AS} 473 \mathrm{~A}} \mathrm{PKB} /$ Akt (dark grey bar). ${ }^{* * *}(\mathrm{p}<0.001)$ indicates statistically significant difference from expression of SLC6A19 alone. C: Arithmetic means \pm SEM $(n=8-16)$ of the normalized L-leucine (2 mM)-induced current $\left(\mathrm{I}_{\mathrm{le}}\right)$ in Xenopus oocytes injected with water (first dotted bar) or Collectrin (second dotted bar) or expressing SLC6A19 without (white bar) or with (black bar) PKB/ Akt alone or coexpressed with Collectrin (dark grey bar). ${ }^{* * *}(\mathrm{p}<0.001)$ indicates significant difference from the absence of PKB/Akt. \# ( $p<0.05)$ indicates significant difference from the absence Collectrin.

Fig. 2. Coexpression of $\mathrm{PKB} /$ Akt enhanced the maximal L-leucine transport rate in SLC6A19expressing Xenopus oocytes. Arithmetic means \pm SEM ( $n=14-19)$ of L-leucine-induced current $\left(\mathrm{I}_{\mathrm{le}}\right)$ as a function of the extracellular L-leucine concentration in Xenopus oocytes expressing SLC6A19 without (white circles) and with PKB/ Akt (black circles).

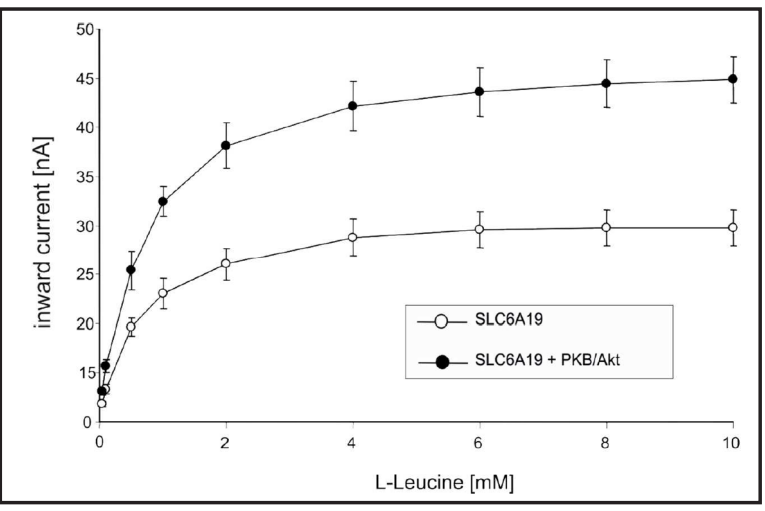

SLC6A19- and PKB/Akt the additional expression of ${ }^{5318 A}$ PIKfyve tended to decrease $\mathrm{I}_{\mathrm{le}}$, an effect, however, not reaching statistical significance. Thus, it remains uncertain, whether or

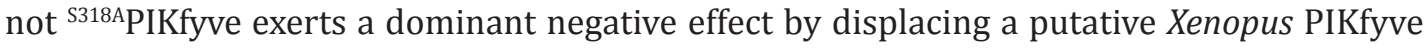
homologue, which could, in theory, mediate the effect of PKB in the absence of exogenous wild type PIKfyve.

The enhanced maximal SLC6A19 activity following PKB/Akt coexpression could result from increased carrier protein abundance in the plasma membrane. To explore this possibility, chemiluminescence experiments were performed. As illustrated in Fig. 4, the coexpression of PKB/Akt resulted in a significant increase in the SLC6A19 protein abundance within the oocyte plasma membrane. 
Fig. 3. The effect of $\mathrm{PKB} /$ Akt was augmented by wildtype PIKfyve but not by PKB/

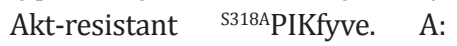
Representative original tracings showing L-leucine (2 $\mathrm{mM}$ )induced current $\left(\mathrm{I}_{\mathrm{le}}\right)$ in Xenopus oocytes injected with water (a), expressing SLC6A19 alone (b), or coexpressing SLC6A19 with PKB/Akt (c-e) without (c) or with additional expression of wild-type PIKfyve (d) or of PKB/

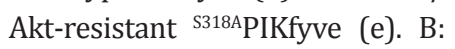
Arithmetic means \pm SEM ( $\mathrm{n}=12$ 19) of the normalized L-leucine (2 mM)-induced current $\left(\mathrm{I}_{\mathrm{le}}\right)$ in Xenopus oocytes injected with water (dotted bar), or expressing SLC6A19 without (white bar) or with PKB/Akt cRNA without (black bar) or with additional coexpression of wild-type PIKfyve (dark grey bar) or of PKB/Akt-resistant ${ }^{\text {S318APIKfyve }}$ (light grey bar). ** $\quad(\mathrm{p}<0.01)$ indicates significant difference

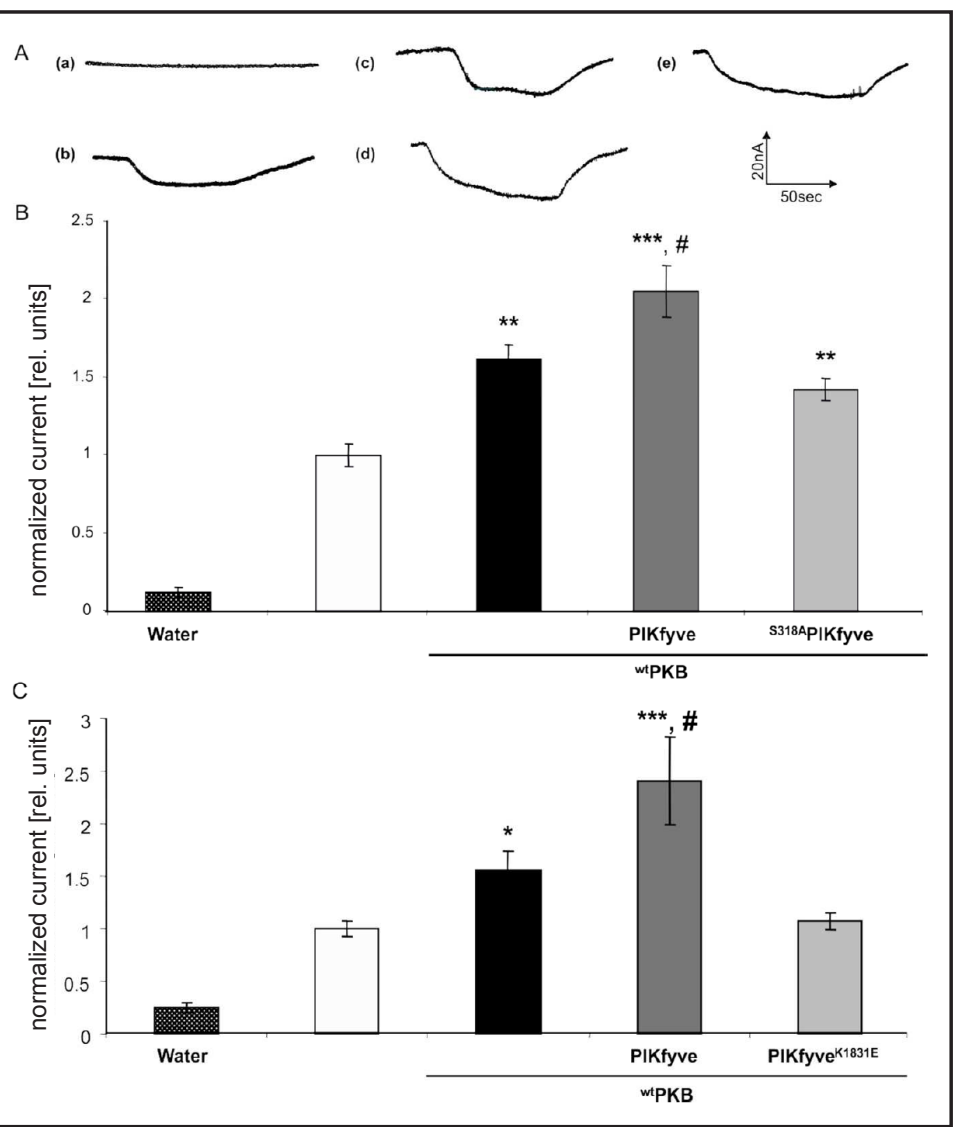
from the absence of PKB/Akt. \# ( $<<0.05$ ) indicates significant difference from the absence of wild-type PIKfyve. C: Arithmetic means \pm SEM $(n=5-11)$ of the normalized L-leucine $(2 \mathrm{mM})$-induced current $\left(\mathrm{I}_{\mathrm{le}}\right)$ in Xenopus oocytes injected with water (dotted bar), or expressing SLC6A19 without (white bar) or with PKB/Akt cRNA without (black bar) or with additional coexpression of wild-type PIKfyve (dark grey bar) or a dominantnegative PIKfyve $\mathrm{K}^{\mathrm{K} 1831 \mathrm{E}}$ mutant (light grey bar). *,*** $(\mathrm{p}<0.05, \mathrm{p}<0.001)$ indicates significant difference from the absence of PKB/Akt. \# ( $<<0.05)$ indicates significant difference from the absence of wild-type PIKfyve.

Fig. 4. Coexpression of $\mathrm{PKB} /$ Akt enhanced surface SLC6A19 protein abundance in SLC6A19-expressing Xenopus oocytes. A: Arithmetic means \pm SEM ( $n=52-67)$ of the normalized chemiluminescence signal of HA-tagged SLC6A19 in Xenopus oocytes injected with water (dotted bar), or expressing SLC6A19 without (white bar) or with (black bar) additional coexpression of wild-type PKB/Akt. *** $(\mathrm{p}<0.001)$ indicates statistically significant difference from the absence of PKB/Akt.

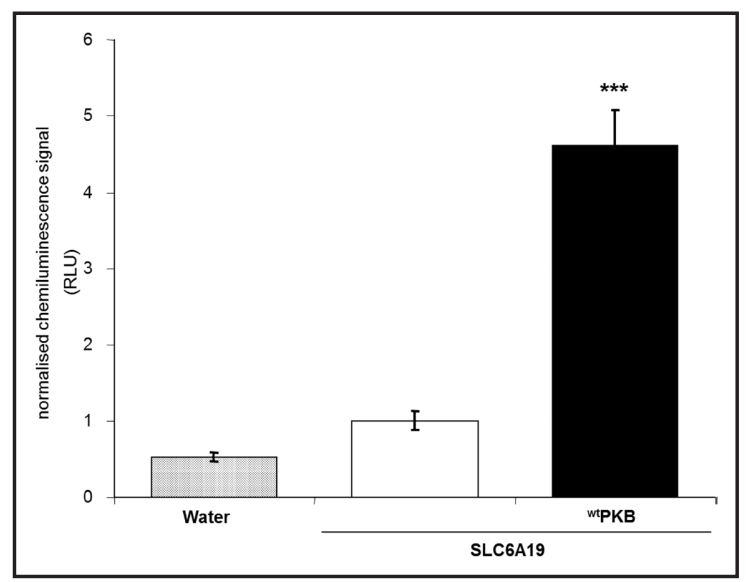

In theory, PKB/Akt could stimulate SLC6A19 by promoting the insertion of carrier protein into the membrane or by delaying carrier retrieval from the membrane. To discriminate between these two possibilities, SLC6A19-expressing Xenopus oocytes were treated with $5 \mu \mathrm{M}$ brefeldin A, an inhibitor of carrier insertion into the cell membrane. As shown in Fig. 5, the L-leucine-induced current declined in the presence of brefeldin A at a similar rate in oocytes expressing SLC6A19 alone and in oocytes expressing SLC6A19 
Fig. 5. Effect of brefeldin A on Xenopus oocytes expressing either SLC6A19 alone or with PKB/Akt. Arithmetic means \pm SEM $(n=22$ 32) of the normalized L-leucine (2 $\mathrm{mM}$ )-induced current $\left(\mathrm{I}_{\mathrm{le}}\right)$ in Xenopus oocytes injected with water (dotted bar) or expressing HA-tagged SLC6A19 without (white bars) or with (black bars) PKB/Akt and incubated in the presence (right bars) or absence (left bars) of $5 \mu \mathrm{M}$

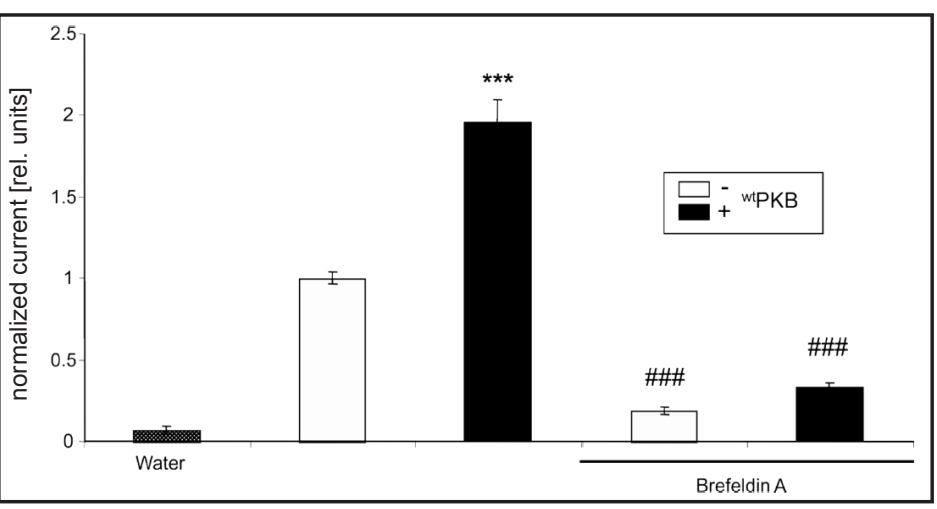
brefeldin $\mathrm{A}$ for 24 hours prior to the measurement. ${ }^{* * *}(\mathrm{p}<0.001)$ indicates significant difference from the absence of PKB/Akt. \#\#\# ( $p<0.001)$ indicates significant difference from the absence of brefeldin A.

together with PKB/Akt. In addition, in the presence of brefeldin A, coexpression of PKB/Akt failed to enhance SLC6A19 activity (Fig. 5). Accordingly, retrieval of carrier protein from the cell membrane was not significantly different between Xenopus oocytes expressing SLC6A19 alone and Xenopus oocytes expressing SLC6A19 together with PKB/Akt. Therefore, PKB/ Akt increased SLC6A19 activity by stimulating carrier protein insertion into rather than by delaying retrieval of carrier protein from the cell membrane.

\section{Discussion}

The present study reveals a novel function of PKB/Akt, i.e. the up-regulation of the neutral amino acid transporter SLC6A19. PKB/Akt, but not its inactive mutant ${ }^{\mathrm{T} 308 \mathrm{~A} / \mathrm{S4} 73 \mathrm{~A} P \mathrm{PKB} /}$ Akt enhanced the maximal transport rate of the carrier. The effect is augmented by additional

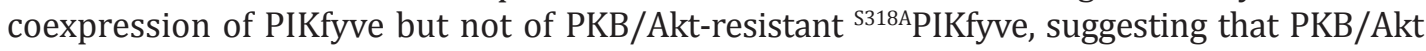
may at least partially be effective through activation of PIKfyve. In view of the decay of L-leucineinduced current following treatment of the Xenopus oocytes with brefeldin A, PKB/Akt appears to stimulate carrier insertion rather than delaying carrier retrieval from the cell membrane. In contrast, SGK1-3 promote SLC6A19 surface abundance by stabilizing the transporter at the plasma membrane [8].

SLC6A19 is dramatically up-regulated by ACE2 and collectrin [40-42], proteins associating with SLC6A19 [40, 42]. SGK1-3 activate SLC6A19 when coexpressed with ACE2, but do not when coexpressed with collectrin [8]. As shown here, PKB/Akt does stimulate transport in oocytes expressing both, SLC6A19 and collectrin. The effect of PKB/Akt is moderate, however, in comparison to the powerful effect of collectrin.

L-Leucine uptake via $\mathrm{Na}^{+}$-coupled transport results in entry of the respective amino acids together with $\mathrm{Na}^{+}$. The $\mathrm{Na}^{+}$taken up is extruded by the $\mathrm{Na}^{+} / \mathrm{K}^{+}$ATPase. Thus SLC6A19 activity results in cellular accumulation of amino acids along with $\mathrm{K}^{+}$and osmotically obliged water and thus in cell swelling [43]. Accordingly, the upregulation of $\mathrm{Na}^{+}$-coupled amino acid transport by PKB/Akt may represent a challenge for cell volume regulation. PKB/Akt activation has indeed been shown to increase cell size [44], an effect, which may not only be based on the stimulation of amino acid uptake, but as well on activation of further carriers resulting in cellular ion accumulation, such as the $\mathrm{Na}^{+} / \mathrm{H}^{+}$exchanger [45].

Cellular uptake of amino acids may foster survival of proliferating cells [46, 47]. Several amino acid transporters have been reported to be critically important for survival and proliferation of cancer cells [48]. Cellular amino acid uptake may stimulate tumor growth by regulating mammalian target of rapamycin (mTOR) through the nutrient pathway [49]. The expression of various amino acid transporters is elevated in a wide spectrum of primary human cancers and may play a critical role in the regulation of growth and survival of cancer cells $[48,50]$. Thus, amino acid transporters are considered potential targets for cancer 
therapy [50]. Along those lines, stimulation of amino acid transport may contribute to the well known tumor-promoting effect of PKB/Akt activity [51-59].

In conclusion, $\mathrm{PKB} / \mathrm{Akt}$ stimulates the $\mathrm{Na}^{+}$-coupled amino acid transporter SLC6A19 $\left(\mathrm{B}^{\circ} \mathrm{AT}\right)$ by promoting carrier insertion into the plasma membrane, an effect possibly involving PIKfyve. Stimulation of SLC6A19 by PKB/AKT may contribute to the regulation of amino acid uptake in intestinal and renal epithelial cells as well as cancer cells.

\section{Acknowledgements}

The authors acknowledge the meticulous preparation of the manuscript by Lejla Subasic and Sari Rübe and the technical support by Elfriede Faber. This study was supported by the Deutsche Forschungsgemeinschaft, GRK 1302, SFB 773 B4/A1, La 315/13-3.

\section{References}

1 Bohmer C, Broer A, Munzinger M, Kowalczuk S, Rasko JE, Lang F, Broer S: Characterization of mouse amino acid transporter B0AT1 (slc6a19). Biochem J 2005;389:745-751.

-2 Broer S, Bailey CG, Kowalczuk S, Ng C, Vanslambrouck JM, Rodgers H, Auray-Blais C, Cavanaugh JA, Broer A, Rasko JE: Iminoglycinuria and hyperglycinuria are discrete human phenotypes resulting from complex mutations in proline and glycine transporters. J Clin Invest 2008;118:3881-3892.

3 Broer S: The role of the neutral amino acid transporter B0AT1 (SLC6A19) in Hartnup disorder and protein nutrition. IUBMB Life 2009;61:591-599.

4 Verrey F, Singer D, Ramadan T, Vuille-dit-Bille RN, Mariotta L, Camargo SM: Kidney amino acid transport. Pflugers Arch 2009;458:53-60.

5 Cheon CK, Lee BH, Ko JM, Kim HJ, Yoo HW: Novel mutation in SLC6A19 causing late-onset seizures in Hartnup disorder. Pediatr Neurol 2010;42:369-371.

-6 Kleta R, Romeo E, Ristic Z, Ohura T, Stuart C, Arcos-Burgos M, Dave MH, Wagner CA, Camargo SR, Inoue S, Matsuura N, Helip-Wooley A, Bockenhauer D, Warth R, Bernardini I, Visser G, Eggermann T, Lee P, Chairoungdua A, Jutabha P, Babu E, Nilwarangkoon S, Anzai N, Kanai Y, Verrey F, Gahl WA, Koizumi A: Mutations in SLC6A19, encoding B0AT1, cause Hartnup disorder. Nat Genet 2004;36:999-1002.

7 Seow HF, Broer S, Broer A, Bailey CG, Potter SJ, Cavanaugh JA, Rasko JE: Hartnup disorder is caused by mutations in the gene encoding the neutral amino acid transporter SLC6A19. Nat Genet 2004;36:10031007.

8 Bohmer C, Sopjani M, Klaus F, Lindner R, Laufer J, Jeyaraj S, Lang F, Palmada M: The serum and glucocorticoid inducible kinases SGK1-3 stimulate the neutral amino acid transporter SLC6A19. Cell Physiol Biochem 2010;25:723-732.

-9 Boehmer C, Okur F, Setiawan I, Broer S, Lang F: Properties and regulation of glutamine transporter SN1 by protein kinases SGK and PKB. Biochem Biophys Res Commun 2003;306:156-162.

10 Boehmer C, Rajamanickam J, Schniepp R, Kohler K, Wulff P, Kuhl D, Palmada M, Lang F: Regulation of the excitatory amino acid transporter EAAT5 by the serum and glucocorticoid dependent kinases SGK1 and SGK3. Biochem Biophys Res Commun 2005;329:738-742.

11 Boehmer C, Palmada M, Rajamanickam J, Schniepp R, Amara S, Lang F: Post-translational regulation of EAAT2 function by co-expressed ubiquitin ligase Nedd4-2 is impacted by SGK kinases. J Neurochem 2006;97:911-921.

-12 Bohmer C, Philippin M, Rajamanickam J, Mack A, Broer S, Palmada M, Lang F: Stimulation of the EAAT4 glutamate transporter by SGK protein kinase isoforms and PKB. Biochem Biophys Res Commun 2004;324:1242-1248.

13 Green CJ, Goransson O, Kular GS, Leslie NR, Gray A, Alessi DR, Sakamoto K, Hundal HS: Use of Akt inhibitor and a drug-resistant mutant validates a critical role for protein kinase B/Akt in the insulin-dependent regulation of glucose and system A amino acid uptake. J Biol Chem 2008;283:27653-27667.

14 Palmada M, Speil A, Jeyaraj S, Bohmer C, Lang F: The serine/threonine kinases SGK1, 3 and PKB stimulate the amino acid transporter ASCT2. Biochem Biophys Res Commun 2005;331:272-277. 


\section{Cellular Physiology $\quad$ Cell Physiol Biochem 2012;30:1538-1546 and Biochemistry \\ Bogatikov/Munoz/Pakladok et al.: PKB/Akt-Sensitive SLC6A19 Activity}

15 Schniepp R, Kohler K, Ladewig T, Guenther E, Henke G, Palmada M, Boehmer C, Rothstein JD, Broer S, Lang F: Retinal colocalization and in vitro interaction of the glutamate transporter EAAT3 and the serum- and glucocorticoid-inducible kinase SGK1 [correction]. Invest Ophthalmol Vis Sci 2004;45:1442-1449.

16 Shojaiefard M, Christie DL, Lang F: Stimulation of the creatine transporter SLC6A8 by the protein kinases SGK1 and SGK3. Biochem Biophys Res Commun 2005;334:742-746.

17 Ikonomov OC, Sbrissa D, Mlak K, Kanzaki M, Pessin J, Shisheva A: Functional dissection of lipid and protein kinase signals of PIKfyve reveals the role of PtdIns 3,5-P2 production for endomembrane integrity. J Biol Chem 2002;277:9206-9211.

-18 Sbrissa D, Ikonomov OC, Shisheva A: PIKfyve, a mammalian ortholog of yeast Fab1p lipid kinase, synthesizes 5-phosphoinositides. Effect of insulin. J Biol Chem 1999;274:21589-21597.

19 Sbrissa D, Ikonomov OC, Deeb R, Shisheva A: Phosphatidylinositol 5-phosphate biosynthesis is linked to PIKfyve and is involved in osmotic response pathway in mammalian cells. J Biol Chem 2002;277:4727647284.

-20 Sbrissa D, Ikonomov OC, Strakova J, Shisheva A: Role for a novel signaling intermediate, phosphatidylinositol 5-phosphate, in insulin-regulated F-actin stress fiber breakdown and GLUT4 translocation. Endocrinology 2004;145:4853-4865.

-21 Ikonomov OC, Sbrissa D, Shisheva A: Mammalian cell morphology and endocytic membrane homeostasis require enzymatically active phosphoinositide 5-kinase PIKfyve. J Biol Chem 2001;276:26141-26147.

22 Ikonomov OC, Sbrissa D, Foti M, Carpentier JL, Shisheva A: PIKfyve controls fluid phase endocytosis but not recycling/degradation of endocytosed receptors or sorting of procathepsin $\mathrm{D}$ by regulating multivesicular body morphogenesis. Mol Biol Cell 2003;14:4581-4591.

23 Ikonomov OC, Sbrissa D, Shisheva A: Localized PtdIns 3,5-P2 synthesis to regulate early endosome dynamics and fusion. Am J Physiol Cell Physiol 2006;291:C393-C404.

-24 Rusten TE, Rodahl LM, Pattni K, Englund C, Samakovlis C, Dove S, Brech A, Stenmark H: Fab1 phosphatidylinositol 3-phosphate 5-kinase controls trafficking but not silencing of endocytosed receptors. Mol Biol Cell 2006;17:3989-4001.

-25 Rutherford AC, Traer C, Wassmer T, Pattni K, Bujny MV, Carlton JG, Stenmark H, Cullen PJ: The mammalian phosphatidylinositol 3-phosphate 5-kinase (PIKfyve) regulates endosome-to-TGN retrograde transport. J Cell Sci 2006;119:3944-3957.

26 Berwick DC, Dell GC, Welsh GI, Heesom KJ, Hers I, Fletcher LM, Cooke FT, Tavare JM: Protein kinase B phosphorylation of PIKfyve regulates the trafficking of GLUT4 vesicles. J Cell Sci 2004;117:5985-5993.

27 Watson RT, Pessin JE: Bridging the GAP between insulin signaling and GLUT4 translocation. Trends Biochem Sci 2006;31:215-222.

28 Welsh GI, Hers I, Berwick DC, Dell G, Wherlock M, Birkin R, Leney S, Tavare JM: Role of protein kinase B in insulin-regulated glucose uptake. Biochem Soc Trans 2005;33:346-349.

29 Shojaiefard M, Strutz-Seebohm N, Tavare JM, Seebohm G, Lang F: Regulation of the Na(+), glucose cotransporter by PIKfyve and the serum and glucocorticoid inducible kinase SGK1. Biochem Biophys Res Commun 2007;359:843-847.

30 Seebohm G, Strutz-Seebohm N, Birkin R, Dell G, Bucci C, Spinosa MR, Baltaev R, Mack AF, Korniychuk G, Choudhury A, Marks D, Pagano RE, Attali B, Pfeufer A, Kass RS, Sanguinetti MC, Tavare JM, Lang F: Regulation of endocytic recycling of KCNQ1/KCNE1 potassium channels. Circ Res 2007;100:686-692.

-31 Gehring EM, Lam RS, Siraskar G, Koutsouki E, Seebohm G, Ureche ON, Ureche L, Baltaev R, Tavare JM, Lang F: PIKfyve upregulates CFTR activity. Biochem Biophys Res Commun 2009;390:952-957.

-32 Klaus F, Laufer J, Czarkowski K, Strutz-Seebohm N, Seebohm G, Lang F: PIKfyve-dependent regulation of the Cl- channel ClC-2. Biochem Biophys Res Commun 2009;381:407-411.

-33 Sopjani M, Kunert A, Czarkowski K, Klaus F, Laufer J, Foller M, Lang F: Regulation of the Ca(2+) channel TRPV6 by the kinases SGK1, PKB/Akt, and PIKfyve. J Membr Biol 2010;233:35-41.

-34 Alesutan IS, Ureche ON, Laufer J, Klaus F, Zurn A, Lindner R, Strutz-Seebohm N, Tavare JM, Boehmer C, Palmada M, Lang UE, Seebohm G, Lang F: Regulation of the glutamate transporter EAAT4 by PIKfyve. Cell Physiol Biochem 2010;25:187-194.

35 Gehring EM, Zurn A, Klaus F, Laufer J, Sopjani M, Lindner R, Strutz-Seebohm N, Tavare JM, Boehmer C, Palmada M, Lang UE, Seebohm G, Lang F: Regulation of the glutamate transporter EAAT2 by PIKfyve. Cell Physiol Biochem 2009;24:361-368. 


\section{Cellular Physiology $\quad$ Cell Physiol Biochem 2012;30:1538-1546 and Biochemistry \\ Bogatikov/Munoz/Pakladok et al.: PKB/Akt-Sensitive SLC6A19 Activity}

-36 Seebohm G, Strutz-Seebohm N, Baltaev R, Korniychuk G, Knirsch M, Engel J, Lang F: Regulation of KCNQ4 potassium channel prepulse dependence and current amplitude by SGK1 in Xenopus oocytes. Cell Physiol Biochem 2005;16:255-262.

-37 Rexhepaj R, Dermaku-Sopjani M, Gehring EM, Sopjani M, Kempe DS, Foller M, Lang F: Stimulation of electrogenic glucose transport by glycogen synthase kinase 3. Cell Physiol Biochem 2010;26:641-646.

-38 Hosseinzadeh Z, Bhavsar SK, Sopjani M, Alesutan I, Saxena A, Dermaku-Sopjani M, Lang F: Regulation of the glutamate transporters by JAK2. Cell Physiol Biochem 2011;28:693-702.

-39 Dermaku-Sopjani M, Sopjani M, Saxena A, Shojaiefard M, Bogatikov E, Alesutan I, Eichenmuller M, Lang F: Downregulation of NaPi-IIa and NaPi-IIb Na-coupled phosphate transporters by coexpression of Klotho. Cell Physiol Biochem 2011;28:251-258.

-40 Camargo SM, Singer D, Makrides V, Huggel K, Pos KM, Wagner CA, Kuba K, Danilczyk U, Skovby F, Kleta R, Penninger JM, Verrey F: Tissue-specific amino acid transporter partners ACE2 and collectrin differentially interact with hartnup mutations. Gastroenterology 2009;136:872-882.

41 Danilczyk U, Sarao R, Remy C, Benabbas C, Stange G, Richter A, Arya S, Pospisilik JA, Singer D, Camargo SM, Makrides V, Ramadan T, Verrey F, Wagner CA, Penninger JM: Essential role for collectrin in renal amino acid transport. Nature 2006;444:1088-1091.

42 Kowalczuk S, Broer A, Tietze N, Vanslambrouck JM, Rasko JE, Broer S: A protein complex in the brushborder membrane explains a Hartnup disorder allele. FASEB J 2008;22:2880-2887.

43 Lang F, Busch GL, Ritter M, Volkl H, Waldegger S, Gulbins E, Haussinger D: Functional significance of cell volume regulatory mechanisms. Physiol Rev 1998;78:247-306.

44 Rodriguez J, Vernus B, Toubiana M, Jublanc E, Tintignac L, Leibovitch S, Bonnieu A: Myostatin inactivation increases myotube size through regulation of translational initiation machinery. J Cell Biochem 2011;

45 Bhandaru M, Yang W, Rotte A, Pasham V, Lang F: Regulation of $\mathrm{Na}(+) / \mathrm{H}(+)$ exchanger in dendritic cells by Akt2. Pflugers Arch 2011;

-46 McGivan JD, Bungard CI: The transport of glutamine into mammalian cells. Front Biosci 2007;12:874-882.

47 Medina MA: Glutamine and cancer. J Nutr 2001;131:2539S-2542S.

48 Ganapathy V, Thangaraju M, Prasad PD: Nutrient transporters in cancer: relevance to Warburg hypothesis and beyond. Pharmacol Ther 2009;121:29-40.

49 Nakanishi T, Tamai I: Solute carrier transporters as targets for drug delivery and pharmacological intervention for chemotherapy. J Pharm Sci 2011;100:3731-3750.

50 Fuchs BC, Bode BP: Amino acid transporters ASCT2 and LAT1 in cancer: partners in crime? Semin Cancer Biol 2005;15:254-266.

51 Carnero A: The PKB/AKT pathway in cancer. Curr Pharm Des 2010;16:34-44.

-52 Chin YR, Toker A: Akt isoform-specific signaling in breast cancer: uncovering an anti-migratory role for palladin. Cell Adh Migr 2011;5:211-214.

53 Ching CB, Hansel DE: Expanding therapeutic targets in bladder cancer: the PI3K/Akt/mTOR pathway. Lab Invest 2010;90:1406-1414.

-54 Dienstmann R, Rodon J, Markman B, Tabernero J: Recent developments in anti-cancer agents targeting PI3K, Akt and mTORC1/2. Recent Pat Anticancer Drug Discov 2011;6:210-236.

55 Dillon RL, Muller WJ: Distinct biological roles for the akt family in mammary tumor progression. Cancer Res 2010;70:4260-4264.

-56 Georgescu MM: PTEN Tumor Suppressor Network in PI3K-Akt Pathway Control. Genes Cancer 2010;1:1170-1177.

57 Martelli AM, Evangelisti C, Follo MY, Ramazzotti G, Fini M, Giardino R, Manzoli L, McCubrey JA, Cocco L: Targeting the Phosphatidylinositol 3-Kinase/Akt/Mammalian Target of Rapamycin Signaling Network in Cancer Stem Cells. Curr Med Chem 2011;18:2715-2726.

58 Steelman LS, Chappell WH, Abrams SL, Kempf RC, Long J, Laidler P, Mijatovic S, Maksimovic-Ivanic D, Stivala F, Mazzarino MC, Donia M, Fagone P, Malaponte G, Nicoletti F, Libra M, Milella M, Tafuri A, Bonati A, Basecke J, Cocco L, Evangelisti C, Martelli AM, Montalto G, Cervello M, McCubrey JA: Roles of the Raf/MEK/ ERK and PI3K/PTEN/Akt/mTOR pathways in controlling growth and sensitivity to therapy-implications for cancer and aging. Aging (Albany NY) 2011;3:192-222.

59 Viglietto G, Amodio N, Malanga D, Scrima M, De Marco C: Contribution of PKB/AKT signaling to thyroid cancer. Front Biosci 2011;16:1461-1487. 